\title{
Increased Terrigenous Input from North America to the Northern Mendeleev Ridge (Western Arctic Ocean) Since the Mid-Brunhes Event
}

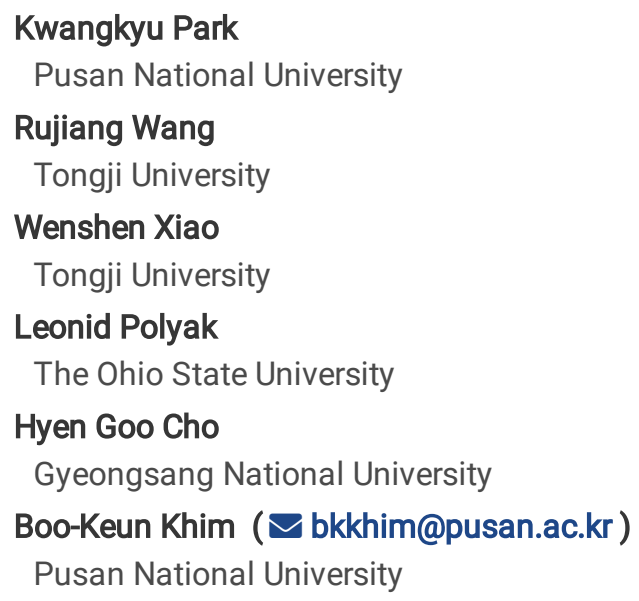

\section{Research Article}

Keywords:

Posted Date: January 31st, 2022

DOI: https://doi.org/10.21203/rs.3.rs-1287030/v1

License: @ (i) This work is licensed under a Creative Commons Attribution 4.0 International License. Read Full License 


\section{Abstract}

Mid-Brunhes Event (MBE) occurred at approximately 420 ka between Marine Isotope Stage 11 and 12, and is considered the most pronounced climatic shift during the last $\sim 800$ kyrs. On the other hand, it is unclear if the MBE was global, despite being observed in the high-latitude Northern Hemispheric cryosphere in terms of climate systems. A 5.35-m long gravity core ARC5-MA01 was obtained from the northern Mendeleev Ridge in the western Arctic Ocean to track the paleoenvironmental changes in terms of the terrigenous sedimentation in response to the glacial-interglacial climate changes across the MBE. Geochemical proxies (biogenic opal, total organic carbon, $\mathrm{C} / \mathrm{N}$ ratio, carbon isotope of organic matter, and calcium carbonate) of MA01 suggest that the terrigenous input was generally higher during the interglacial periods. Based on a mineralogical examination, most of the terrigenous input was attributed to the abundance of dolomite and the increased kaolinite content from North America. In particular, most paleoceanographic proxies showed that the terrigenous input from North America was enhanced distinctly during the post-MBE interglacial periods. These results suggest that the MBE in the western Arctic Ocean was a global climatic shift closely linked to cryospheric development in North America during the middle Pleistocene.

\section{Introduction}

The glacial-interglacial (G-IG) changes paced by the variations in the orbital parameters were the most pronounced climate fluctuations during the Quaternary, which is highlighted by the onset of Northern Hemisphere glaciation ${ }^{1}$. The global terrestrial, marine, and ice archives clearly showed that climatic variations during the recent one-third of the Quaternary ( $800 \mathrm{kyrs})$ are predominated by 100-kyr G-IG cycles, particularly during the last four cycles ${ }^{1,2}$. A distinct global climatic shift, called the Mid-Brunhes Event (MBE), occurred at Marine Isotope Stage (MIS) 11/12, which coincides with the largest fluctuation in amplitudes of benthic $\delta^{18} \mathrm{O}$ values over the Quaternary ${ }^{1,3}$. During the interglacial periods since the MBE, the Antarctic ice core records showed warmer air temperatures and higher atmospheric $\mathrm{CO}_{2}$ concentrations, compared with those in earlier interglacial periods ${ }^{4,5}$. Lang and Wolff $(2011)^{6}$ suggested, based on the diverse paleoclimatic data collected from south of $\sim 60^{\circ} \mathrm{N}$, that the MBE was a global event related to the stronger interglacials and terminations during the last $\sim 450 \mathrm{kyrs}$. In contrast, the climatic amplitudes during the glacial periods remain less pronounced.

Although climate change during the MBE has been reported worldwide from the terrestrial, marine, and ice core records, only a few studies have been conducted in the Arctic Ocean where the climatic changes fluctuated more severely than the other oceans ${ }^{7}$. For example, based on the $\mathrm{Mg} / \mathrm{Ca}$ ratios in ostracodes from the western Arctic Ocean sediments, Cronin et al. (2017) ${ }^{8}$ reported that the thermal maximum events during the transitions from the interglacial to glacial periods since the MBE were related to the inflow of warm Atlantic Water, i.e., enhanced Arctic amplification. Xiao et al. (2020) ${ }^{9}$ suggested that preservation of calcareous microfossils improved across the MBE in the western Arctic Ocean. This phenomenon is related to the decrease in organic matter export and/or weakened bottom water ventilation along with the development of perennial sea ice. In general, the climatic shift across the interglacial-terminations since the MBE was intensified, but the climate changes during the glacial periods across the MBE are poorly resolved. Such a lack of information is typical of the Arctic Ocean, where calcareous microfossil preservation is poor during the glacial periods ${ }^{10}$.

This study examined the geochemical and mineralogical proxies of core ARC5-MA01 (hereafter MA01) in terms of terrigenous sedimentation to reveal the paleoenvironmental changes by orbital-scale glacial activities during the last $~ 840$ krys in the northern Mendeleev Ridge of the western Arctic Ocean. Our results revealed an increase of North American terrigenous input to the western Arctic Ocean since the MBE, supporting a global climatic amplification since the MBE.

\section{Results}

The geochemical results of MA01 clearly show the G-IG cyclic variations during the last 840 kyrs (Figs. 1 and 2). Biogenic opal contents (from 1.2 to $7.4 \%$ with an average of 3.1\%) were higher during interglacial periods (Fig. 2 and Table 2). Total organic carbon (TOC) contents (from 0 to $0.55 \%$ ) increased from the glacial periods (ca. $0.06 \%$ ) to the interglacial periods (ca. 0.08\%) (Fig. 2 and Table 2). In particular, TOC contents were higher and more variable since MIS 11. C/N ratios are higher during the interglacial periods (ca. 1.6) than during the glacial periods (ca. 1.1). Their variations are similar to TOC contents, following higher fluctuations since MIS 11 (Fig. 2). Similar to the biogenic opal and TOC contents, the interglacial $\delta^{13} \mathrm{C}_{\text {org }}$ values $(-23.9 \%$ on average) are higher than the glacial values (-24.5\%o on average) (Fig. 2 and Table 2). Interestingly, $\mathrm{CaCO}_{3}$ content ( 0.4 to $\left.26.2 \%\right)$ associated with dolomite increases since 
MIS 16 (Fig. 2). Its average content was higher during the interglacial periods, together with greater fluctuations since MIS 11 (Fig. 2 and Table 2).

Table 1

List of cores in this study and reference cited.

\begin{tabular}{|c|c|c|c|c|c|}
\hline Core site & Area & Latitude & Longitude & Water depth (m) & Reference \\
\hline ARC5-MA01 & Mendeleev Ridge & $82^{\circ} 01.86^{\prime} \mathrm{N}$ & $178^{\circ} 57.60^{\prime} \mathrm{E}$ & 2,295 & This study, Xiao et al., $2020^{9}$ \\
\hline HLY0501-JPC6 & Chukchi-Alaskan margin & $72^{\circ} 30.71^{\prime} \mathrm{N}$ & $157^{\circ} 02.08^{\prime} \mathrm{W}$ & 673 & Ortiz et al., $2009^{24}$ \\
\hline MR09-03 PC04 & Chukchi Slope & $74^{\circ} 26.30 \mathrm{~N}$ & $165^{\circ} 44.30^{\prime} \mathrm{W}$ & 370 & Park et al., $2017^{13}$ \\
\hline MR09-03 PC01 & Chukchi Slope & $75^{\circ} 28.10^{\prime} \mathrm{N}$ & $165^{\circ} 40.40^{\prime} \mathrm{W}$ & 558 & Park et al., $2017^{13}$ \\
\hline MR08-04 PC1 & Northwind Ridge & $74^{\circ} 48.50^{\prime} \mathrm{N}$ & $158^{\circ} 31.85^{\prime} \mathrm{W}$ & 998 & Rella and Uchida, $2011^{16}$ \\
\hline ARC4-BN05 & Canada Basin & $80^{\circ} 29.04^{\prime} \mathrm{N}$ & $161^{\circ} 27.90^{\prime} \mathrm{W}$ & 3,156 & Dong et al., $2017^{19}$ \\
\hline ARC5-ICE6 & Makarov Basin & $83^{\circ} 37.69^{\prime} \mathrm{N}$ & $161^{\circ} 45.84^{\prime} \mathrm{E}$ & 2,901 & Xiao et al., $2021^{21}$ \\
\hline PS2178-5 & Makarov Basin & $88^{\circ} 01.50^{\prime} \mathrm{N}$ & $159^{\circ} 42.20^{\prime} \mathrm{E}$ & 4,008 & Schubert and Stein, $1997^{11}$ \\
\hline PS2185-6 & Lomonosov Ridge & $87^{\circ} 32.20^{\prime} \mathrm{N}$ & $144^{\circ} 55.60^{\prime} \mathrm{E}$ & 1,052 & Schubert and Stein, $1997^{11}$ \\
\hline PS2174-5 & Amundsen Basin & $87^{\circ} 29.10^{\prime} \mathrm{N}$ & $91^{\circ} 32.60^{\prime} \mathrm{E}$ & 4,427 & Schubert and Stein, $1997^{11}$ \\
\hline
\end{tabular}


Table 2

Statistical summary of geochemical and mineralogical results of MA01 for interglacial and glacial periods during the last $840 \mathrm{ky}$ and post-MBE (after $424 \mathrm{ka}$ ) and pre-MBE (before $424 \mathrm{ka}$ ).

\begin{tabular}{|c|c|c|c|c|c|c|c|c|c|c|c|c|}
\hline & & $\begin{array}{l}\text { B- } \\
\text { opal } \\
(\%)\end{array}$ & $\begin{array}{l}\text { TOC } \\
(\%)\end{array}$ & $\mathrm{C} / \mathrm{N}$ & $\begin{array}{l}\delta^{13} C_{\text {org }} \\
(\%)\end{array}$ & $\begin{array}{l}\mathrm{CaCO}_{3} \\
(\%)\end{array}$ & $\begin{array}{l}\text { PF } \\
\left(\# / g / 10^{3}\right)\end{array}$ & $\begin{array}{l}>154 \\
\mathrm{~mm} \\
(\%)\end{array}$ & $\begin{array}{l}\text { Kaolinite } \\
(\%)\end{array}$ & $\begin{array}{l}\text { Smectite } \\
(\%)\end{array}$ & $\begin{array}{l}\text { Illite } \\
(\%)\end{array}$ & $\begin{array}{l}\text { Chlorite } \\
(\%)\end{array}$ \\
\hline \multirow{4}{*}{$\begin{array}{l}\text { Interglacial } \\
\text { (MIS 1, 3, } \\
\text {..., and 21) }\end{array}$} & Average & 3.2 & 0.08 & 1.6 & -23.9 & 3.6 & 0.98 & 2.4 & 16 & 7 & 58 & 20 \\
\hline & Min & 1.2 & 0.00 & 0.0 & -25.6 & 0.4 & 0 & 0.3 & 11 & 1 & 38 & 17 \\
\hline & Max & 7.4 & 0.55 & 15.4 & -22.8 & 26.2 & 9.61 & 17.4 & 29 & 14 & 65 & 25 \\
\hline & Std. & 1.0 & 0.10 & 2.0 & 0.7 & 4.0 & 1.73 & 2.6 & 4 & 2 & 5 & 2 \\
\hline \multirow{4}{*}{$\begin{array}{l}\text { Glacial } \\
\text { (MIS 2,4, } \\
\text {..., and 20) }\end{array}$} & Average & 3.0 & 0.06 & 1.1 & -24.5 & 2.4 & 0.10 & 2.4 & 14 & 6 & 60 & 20 \\
\hline & Min & 1.2 & 0.00 & 0.0 & -25.7 & 0.5 & 0 & 0.3 & 11 & 2 & 47 & 15 \\
\hline & Max & 5.0 & 0.35 & 7.8 & -23.2 & 12.1 & 2.14 & 30.1 & 23 & 16 & 65 & 23 \\
\hline & Std. & 0.7 & 0.06 & 1.3 & 0.6 & 2.4 & 0.39 & 3.5 & 2 & 3 & 4 & 2 \\
\hline \multirow{4}{*}{$\begin{array}{l}\text { Post-MBE } \\
\text { interglacial } \\
\text { (MIS 1,3, } \\
\text {..., and 11) }\end{array}$} & Average & 3.1 & 0.14 & 2.7 & -23.9 & 5.6 & 1.92 & 3.7 & 18 & 7 & 56 & 20 \\
\hline & Min & 1.2 & 0.00 & 0.0 & -25.6 & 0.4 & 0 & 0.5 & 12 & 1 & 38 & 17 \\
\hline & Max & 7.4 & 0.55 & 15.4 & -22.8 & 26.2 & 9.61 & 17.4 & 29 & 14 & 64 & 25 \\
\hline & Std. & 1.0 & 0.11 & 2.3 & 0.7 & 4.7 & 2.02 & 2.9 & 5 & 3 & 6 & 2 \\
\hline \multirow{4}{*}{$\begin{array}{l}\text { Post-MBE } \\
\text { glacial } \\
\text { (MIS 2, 4, } \\
\text {..., and 10) }\end{array}$} & Average & 2.7 & 0.10 & 2.1 & -24.5 & 3.5 & 0.30 & 4.3 & 16 & 5 & 59 & 21 \\
\hline & Min & 1.2 & 0.03 & 0.6 & -25.7 & 0.7 & 0 & 0.5 & 13 & 2 & 47 & 19 \\
\hline & Max & 4.6 & 0.35 & 7.8 & -23.2 & 11.7 & 2.14 & 30.1 & 23 & 8 & 65 & 23 \\
\hline & Std. & 0.8 & 0.07 & 1.6 & 0.8 & 3.0 & 0.65 & 5.5 & 3 & 2 & 5 & 1 \\
\hline \multirow{4}{*}{$\begin{array}{l}\text { Pre-MBE } \\
\text { interglacial } \\
\text { (MIS } 13 \text {, } \\
15, \ldots . \text {, and } \\
21 \text { ) }\end{array}$} & Average & 3.2 & 0.03 & 0.5 & -24.0 & 1.6 & 0 & 1.2 & 13 & 7 & 60 & 20 \\
\hline & Min & 1.6 & 0.00 & 0.0 & -25.2 & 0.7 & 0 & 0.3 & 11 & 2 & 56 & 17 \\
\hline & Max & 7.1 & 0.19 & 3.9 & -23.4 & 8.7 & 0.01 & 9.8 & 17 & 10 & 65 & 24 \\
\hline & Std. & 0.9 & 0.03 & 0.5 & 0.5 & 1.3 & 0 & 1.5 & 1 & 2 & 2 & 1 \\
\hline \multirow{4}{*}{$\begin{array}{l}\text { Pre-MBE } \\
\text { glacial } \\
\text { (MIS 12, } \\
14, \ldots . \text {, and } \\
20 \text { ) }\end{array}$} & Average & 3.1 & 0.03 & 0.7 & -24.4 & 1.9 & 0 & 1.5 & 13 & 7 & 60 & 20 \\
\hline & Min & 2.0 & 0.00 & 0.0 & -25.2 & 0.5 & 0 & 0.29 & 11 & 3 & 51 & 15 \\
\hline & Max & 5.0 & 0.16 & 4.1 & -23.7 & 12.1 & 0.01 & 7.02 & 18 & 16 & 64 & 23 \\
\hline & Std. & 3.2 & 0.03 & 1.6 & -23.9 & 3.6 & 0.98 & 2.43 & 16 & 7 & 58 & 20 \\
\hline
\end{tabular}

$\mathrm{C} / \mathrm{N}$ ratio is positively correlated with TOC content during the interglacial periods $\left(r^{2}=0.88\right)$, particularly strong during the glacial periods $\left(r^{2}=0.97\right)$ (Fig. 3). It is also positively correlated with $\mathrm{CaCO}_{3}$ content between the interglacial $\left(r^{2}=0.70\right)$ and glacial $\left(r^{2}=0.60\right)$ periods

(Fig. 3). Modest correlation is observed between $\mathrm{TOC}$ and $\mathrm{CaCO}_{3}$ contents $\left(\mathrm{r}^{2}=0.55 \sim 0.59\right)$, regardless of the G-IG cycles (Fig. 3). On the other hand, $\delta^{13} \mathrm{C}_{\text {org }}$ values are very poorly correlated with either $\mathrm{C} / \mathrm{N}$ ratio $\left(r^{2}<0.01\right)$ or TOC content $\left(r^{2}<0.01\right)$. Nonetheless, several low $\delta^{13} \mathrm{C}_{\text {org }}$ values (<-25\%) coincide with the peaks of $\mathrm{CaCO}_{3}$ content during MIS 16,13 , and 8 to 7 (Fig. 2).

The relative contents of the four major clay minerals show that illite (38-65\%, average $59 \%)$ was the most abundant. The other clay minerals (kaolinite, chlorite, and smectite) occupied 15\% (11-29\%), 20\% (15-25\%), and 6\% (1-16\%) on average, respectively (Fig. 4 and Supplementary Fig. S1). Despite the low resolution, the clay minerals of MA01 appeared to show G-IG cyclic variations during the last $\sim 840 \mathrm{kyrs}$ (Fig. 4). Although the variation pattern seems similar among kaolinite, smectite, and chlorite, it is noticed that smectite and kaolinite contents increased during the interglacial periods, particularly since MIS 11, similar to the pattern of geochemical proxies (Fig. 5). These variations were differentiated more clearly between the glacial and interglacial periods since the MBE (Fig. 5; Table 2). 
Based on carbonate quantification, most TIC consists of dolomite during the last $\sim 840$ kyrs (Figs. 2 and 4 ). The calcite accounts partly for TIC during the warm periods since MIS 7, corresponding to the peaks of planktonic foraminiferal abundance (Fig. 4). In addition, $\mathrm{CaCO}_{3}$ peaks associated with dolomite peaks during MIS $16,13,7,5$, and 3 coincide with the intervals of high kaolinite contents and coarse fractions (Fig. 4).

\section{Discussion}

Glacial-interglacial changes of geochemical and mineralogical proxies in the northern Mendeleev Ridge during the last 840 kyrs

The geochemical proxies of core MA01 were characterized by G-IG cycles and, particularly, by the long-term change during the last $\sim 840$ kyrs (Fig. 2). The biogenic opal content, representing the primary productivity of the surface seawater, is low (3.1\% on average), which was attributed to the year-round sea ice cover in the central western Arctic Ocean ${ }^{11,12}$. Such a low biogenic opal content is similar to those in the cores from the central-to-eastern Arctic Ocean ( 2-4\% on average) ${ }^{11}$ and the Chukchi Rise (3.7-4.4\% on average $)^{13}$ located northwest and southeast to the Mendeleev Ridge, respectively. In the Northwind Ridge, based on foraminiferal assemblages, Polyak et al. (2013) ${ }^{12}$ reported that the perennial sea ice condition was established at $\sim 0.8 \mathrm{Ma}$. This is consistent with the overall low primary productivity in the present study, suggesting that the northern Mendeleev Ridge was covered dominantly with perennial sea ice during the last $840 \mathrm{ka}$. Despite low, the biogenic opal content in this study was slightly different between glacial and interglacial periods, particularly higher (up to 7.4\%) during MIS 5, 7, and 13 (Fig. 2). Such difference between the glacial and interglacial periods was also reported from the central Arctic Ocean ${ }^{11}$ and the Chukchi Rise ${ }^{13}$. Schubert and Stein $(1996)^{11}$ attributed that the low biogenic opal content during the glacial periods was attributed to both the reduced marine productivity and the increased input of terrigenous sediments. The lower biogenic opal content in the northern Mendeleev Ridge during the glacial periods can be explained in a similar reason to Schubert and Stein (1996) ${ }^{11}$. Thus, based on the occurrence of planktonic foraminiferal tests in MA01 which is in line with the G-IG variability of the biogenic opal content during the last $~ 840$ kyrs (Figs. 2 and 4), the surface water conditions in the northern Mendeleev Ridge were different between the glacial and interglacial periods.

TOC content and $\mathrm{C} / \mathrm{N}$ ratio also represent the G-IG changes in the surface water conditions in the northern Mendeleev Ridge (Fig. 2 and Table 2). Similar to the biogenic opal content, the TOC content exhibited G-IG variability characterized by a high and low content during interglacial and glacial periods, respectively. Despite the generally low $\mathrm{C} / \mathrm{N}$ ratios due to the low $\mathrm{TOC}$ content and, thus, its dominant effect on total nitorogen ${ }^{14}$, the strong positive correlation $\left(r^{2}=0.88\right.$ for interglacial periods and $r^{2}=0.97$ for glacial periods) between TOC contents and $\mathrm{C} / \mathrm{N}$ ratios indicates that higher TOC contents were attributed to higher contribution of terrestrial organic matter than the enhanced surface water productivity in the northern Mendeleev Ridge (Figs. 2 and 3). The strong contribution of terrestrial organic matter in the northern Mendeleev Ridge is supported by the generally low $\delta^{13} \mathrm{C}_{\text {org }}$ values (Fig. 2). Previous studies also reported a higher input of terrestrial organic matter during the glacial periods in the western Arctic Ocean ${ }^{15,16}$. Yamamoto and Polyak $(2009)^{15}$ suggested that the increased input of terrestrial organic matter during the cold periods in the southern Mendeleev Ridge was associated with the more efficient transport of glaciogenic fine-grained particles from the continent to the western Arctic Ocean. In the Chukchi Borderland, the increase in TOC content was mostly associated with the low coarse-grained $(>150 \mu \mathrm{m})$ fraction during the cold periods, whereas the marine production of organic carbon more likely increased during the warm periods ${ }^{16}$. In contrast, our record from the northern Mendeleev Ridge shows higher TOC content during the interglacial periods rather than the glacial periods (Figs. 2 and 4).

Rella and Uchida (2011) ${ }^{16}$ reported that TOC content was negatively correlated with $\mathrm{CaCO}_{3}$ and coarse fraction contents in the Chukchi Borderland. For example, the high TOC content was accompanied by a low $\mathrm{CaCO}_{3}$ and coarse fraction contents, which resulted from the transport of terrestrial organic matter from $\mathrm{CaCO}_{3}$-poor areas such as Siberian margins and/or the less $\mathrm{CaCO}_{3}$ transport to the Chukchi Borderland. In contrast, the geochemical results of this study showed that $\mathrm{CaCO}_{3}$ content was positively correlated with TOC content $\left(r^{2}=0.55-59\right)$ and $\mathrm{C} / \mathrm{N}$ ratio $\left(r^{2}=0.60-70\right)$ (Fig. 3). Hence, $\mathrm{CaCO}_{3}$ and TOC contents are mainly terrigenous in origin, similar to studies in the eastern-central Arctic Ocean ${ }^{11,17}$. Such terrigenous contributions are evidenced by the peaks of the coarse fraction and dolomite contents (Figs. 2 and 4). This suggests that the inorganic carbon components, consisting mostly of dolomite, originate mainly from the Canadian Arctic Archipelago and Mackenzie watershed $9,13,18,19$. Thus, the terrigenous input in MA01 was sourced mainly from northern North America. These findings suggest that the regions far from the continental shelf in the western Arctic Ocean are affected more by sediment deposition from North America than the Siberian margin. Such increased terrigenous input requires an enhanced Beaufort Gyre in the western Arctic Ocean, leading to the transport of more sediments from North America to the northern Mendeleev 
Ridge $^{20}$. Thus, the geochemical and bulk mineral results of MA01 indicate that sediment transport from North America to the western Arctic Ocean, which generally stagnated during the glacial periods, was activated during the deglacial and stadial periods.

The strong G-IG variabilities were also observed in the variation of the major clay mineral compositions of MA01 (Fig. 4 and Supplementary Fig. S1). The overall predominance of illite is in good accord with previous studies in the western Arctic Ocean ${ }^{13,19}$. Nonetheless, the other minor clay minerals have been used for the provenance studies ${ }^{13,19,21}$. Smectite content in the western Arctic Ocean is very low due to its long distance from the main source areas in the eastern Arctic margins ${ }^{13,19,22}$, although the content is relatively high in the central-western Arctic Ocean ${ }^{21,23}$. Similar to this study in the northern Mendeleev Ridge, the very low smectite content was reported from the Chukchi Rise (7-9\% on average) ${ }^{13}$ and the Canada Basin (3\% on average) ${ }^{19}$ in the western Arctic Ocean. Despite the low content, the smectite content of MA01 seems different between the glacial and interglacial periods since the MBE (Fig. 4).

In the Chukchi-Alaskan Slope, chlorite was used as a proxy for the Pacific inflow through the Bering Strait ${ }^{24}$. On the other hand, chlorite is also distributed abundantly in the East Siberian margin ${ }^{14}$. Due to the wide distribution of chlorite along the continental margins of the western Arctic Ocean, its G-IG cycles were less detectable in the Chukchi Rise ${ }^{13}$ and Canada Basin ${ }^{19}$ and the northern Mendeleev Ridge of this study area (Fig. 4 and Table 2). In comparison, kaolinite in the western Arctic Ocean reflects a specific source area, i.e., northern Canada and Alaska ${ }^{25}$. Moreover, its content was fairly variable among the clay mineral assemblage in the Chukchi Rise and Canada Basin ${ }^{13,19}$. Similarly, the kaolinite content of MA01 showed strong G-IG variability (Figs. 4 and 5; Table 2). Recently, Xiao et al. $(2021)^{21}$ argued that the kaolinite was transported from Franz Joseph Land in the Barents Sea to the Makarov Basin at several glacial/deglacial events including MIS 6 and 4/3. However, no prominent kaolinite peak was observed at these events in MA01 (Fig. 4), presumably due to the different sedimentation regimes between the northern Mendeleev Ridge and the Makarov Basin. The distinct kaolinite peaks of MA01 coincided with the detrital carbonate peaks (e.g., calcite, dolomite, and XRF-Ca/Al) indicative of the enhanced terrigenous input from North America during MIS 16, 13, 7, 5, and 3 (Figs. 2 and 4). This suggests that the clay-sized particles were also delivered with the coarse fraction from North America to the northern Mendeleev Ridge.

Park et al. (2017) ${ }^{13}$ attributed the high kaolinite content in the Chukchi Rise to more terrigenous input from North America. The terrigenous input was more active during the deglacial period than the peak glacial period when the terrestrial glaciation and sea ice were most intensive ${ }^{13,26}$, which strongly reduced sediment transportation to the western Arctic Ocean ${ }^{27,28}$. Accordingly, in the northern Mendeleev Ridge, the terrigenous input increased during the deglacial periods and/or interglacial periods when more terrigenous sediments could be transported efficiently from North America via iceberg and/or sea ice in open water condition.

Increased terrigenous input to the northern Medeleeve Ridge since the MBE and its paleoenvironmental implications

The geochemical and mineralogical results of MA01 show an amplification of G-IG contrast across the MBE (Fig. 5 and Table 2). Particularly, $\mathrm{TOC}$ and $\mathrm{CaCO}_{3}$ contents, $\mathrm{C} / \mathrm{N}$ ratio, and kaolinite content associated with the dolomite peaks were distinctly high during the post-MBE interglacial periods, suggesting the enhanced terrigenous input from North America (Figs. 2, 4, and 5 and Table 2). The terrestrial and marine records as well as modeling results suggest that the continental ice sheets in North America grew remarkably during the late Quaternary ${ }^{29-32}$. In the northern North Atlantic, glaciogenic marine sediments were observed since the PliocenePleistocene transition, while the detrital carbonate sediments from North America started to appear since MIS $16^{33}$. Similarly, in the western Arctic Ocean, detrital carbonate occurred distinctly since MIS 16, indicating an expansion of the North American ice sheets ${ }^{9,34}$. Hence, the sediment input that originated from North America to the western Arctic Ocean increased during the middle Pleistocene as a result of the development of the North American ice sheets. Such increased terrigenous input to the northern Mendeleev Ridge was evidenced by our multiproxy results that were characterized by the more distinct G-IG fluctuation since the MBE (Fig. 5 and Table 2), while the first extensive development of the North American ice sheets occurred at MIS 16 (Fig. 4).

Many records regarding the climatic shift during the post-MBE (since MIS 11) are distinguished by the strong interglacial conditions represented by warmer seawater temperatures, higher atmospheric $\mathrm{CO}_{2}$ concentrations, and smaller ice volume ${ }^{1,4-6,35}$. One possible explanation to the MBE is the gradual removal of continental regoliths in the Northern Hemisphere during the Quaternary 36,37 . Regolith removal, resulting from the repeated glaciation, facilitated silicate weathering of the freshly exposed bedrocks, accelerating the removal of atmospheric $\mathrm{CO}_{2}$ concentration, which enhanced global cooling by positive feedback ${ }^{36-38}$. Clark et al. (2006) ${ }^{36}$ reported that the long-term climate change superimposed G-IG cycles during the Quaternary is closely linked to the increase in ice volume since the early 
Pleistocene. This successive climatic evolution eventually occurred globally as the change in G-IG cycles from $\sim 41$ kyrs to 100 kyrs during the middle Pleistocene $(\sim 700 \mathrm{ka})^{36}$. Based on the geochemical and mineralogical proxies of MA01, such climatic changes related to the ice sheet development on North America occurred first in the northern Mendeleev Ridge at MIS 16 ( 640 ka) and fluctuated distinctly since the MBE (Figs. 2, 4, and 5). Hence, these results support the regolith removal hypothesis because the terrestrial-origin sediment deposition increased since the MBE as a result of the development of the North American ice sheets adjacent to the western Arctic Ocean. The remaining question is why more terrigenous sediments were deposited during the interglacial periods in the northern Mendeleev Ridge of the western Arctic Ocean.

The cooling in the northern Mendeleev Ridge across the MBE can be found not only by the increase in terrigenous input but also by the change in the surface water conditions. Although the cause of the changes in calcareous microfossil abundance in the central-towestern Arctic Ocean remains unclear ${ }^{38,39}$, distinct G-IG contrast of surface water conditions are inferred by biogenic opal content and planktonic foraminiferal abundance of MA01 since MBE (Figs. 2, 4, and 5). The G-IG contrast was particularly amplified since MIS 11 with a decrease (2.7\% on average) of biogenic opal content during the glacial periods (Fig. 5 ; Table 2), which indicates post-MBE colder glacial conditions. Such productivity difference seems to be related to the difference in seawater temperature and sea ice cover between the glacial and interglacial periods. Cronin et al. (2019) ${ }^{40}$ suggested that perennial sea ice developed during the interglacial period across the MBE based on the calcareous microfossil assemblages representing the faunal transition in the western Arctic Ocean. The thick perennial sea ice conditions were settled during the glacial periods ${ }^{40}$, corroborating the gradual cooling regime across the MBE in the northern Mendeleev Ridge. Based on the changes in the microfossil abundance in the central-western Arctic Ocean, Marzen et al. (2016) ${ }^{39}$ reported that the sea-ice related productivity increased during the interstadial periods since the MBE, with modulation by 100 kyrs of G-IG cycles. This suggests that the climate variability was more sensitive in the central-western Arctic Ocean during the strong interstadials compared to the global climate variablity ${ }^{39}$. Due to the high sensitivity to climate change, not only $100 \mathrm{kyr}$ cycle of the G-IG contrast but also shorter ( $<20 \mathrm{kyrs})$ stadial/interstadial variations were recorded in the northern Mendeleev Ridge, leading to more terrigenous input during the interglacial periods. Such high sensitivity to climate change from global cooling eventually occurred as a distinct G-IG contrast in the northern Mendeleev Ridge since the MBE. Continuous regolith removal during the Quaternary has been accelerated since the middle Pleistocene ${ }^{37}$. Such conditions supplied more terrestrial sediments to the northern Mendeleev Ridge in the western Arctic Ocean during the warmer and more extended post-MBE interglacial periods and multiple stadial/interstadial transitions.

\section{Conclusions}

In this study, diverse geochemical and mineralogical proxies of MA01 were analyzed to track paleoenvironmental changes in terms of the terrigenous sediment deposition related to the glacial history during the G-IG climatic changes over the last $~ 840$ kyrs. The overall features of the geochemical and mineralogical results in the northern Mendeleev Ridge accorded with the previous results reported in other regions of the western Arctic Ocean. On the other hand, the partial difference from the central-western Arctic Ocean was attributed to the regional difference in the depositional environment. The most significant differences between the glacial and interglacial periods were the terrigenous input from North America and the sea surface conditions during the post-MBE. This finding aligns well with the regolith removal hypothesis, which has been proposed as one of the primary causes of global cooling and the completion of $\sim 100 \mathrm{G}-\mathrm{IG}$ world during the Pleistocene. This study suggests that the post-MBE G-IG contrast in the northern Mendeleev Ridge resulted from global cooling and internal positive feedback, both of which are closely related to the cryospheric development in North America. Strong G-IG contrast during the post-MBE was observed in the northern Mendeleev Ridge. Nevertheless, diverse regional effects should be considered using other paleoceanographic proxies to understand better the paleoenvironmental history in the western Arctic Ocean.

\section{Materials And Methods}

A 5.35 m-long gravity core MA01 was taken from the northern Mendeleev Ridge ( $178^{\circ} 58^{\prime} \mathrm{E} 82^{\circ} 02^{\prime} \mathrm{N}, 2,295 \mathrm{~m}$ deep) by R/V Xue Long during scientific cruise CHINARE-V in 2012 (Fig. 1). Core sediments were subsampled at $2 \mathrm{~cm}$ intervals at Tongji University (China) and ground after freeze-drying at Pusan National University (Korea) for laboratory analyses. Xiao et al. (2020) ${ }^{9}$ reported the color reflectance, bulk elemental composition, coarse fraction $(>150 \mu \mathrm{m})$, foraminiferal abundance, AMS ${ }^{14} \mathrm{C}$ dating, and paleomagnetic inclination of MA01. The stratigraphy of MA01 was determined to be 840 ka by lithostratigraphic and biostratigraphic regional correlations and tunning of $\mathrm{Mn}$ content to the global climate variability ${ }^{9}$. We note that, the tuning-based stratigraphy before MIS 6 is 
tentative due to the lack of identifiable stratigraphic marker to constrain the Mn variability ${ }^{9}$. This study used the same age model to interpret the data of MA01.

\section{Geochemical measurements}

Geochemical properties were analyzed on a total of 271 samples. Biogenic silica $\left(\mathrm{Si}_{\mathrm{BIO}}\right)$ content was measured using the molybdate blue spectrophotometer following the wet-alkaline sequential extraction method modified from DeMaster $(1981)^{41}$. The biogenic opal content was calculated by multiplying $\mathrm{Si}_{\text {BIO }}$ by $2.4^{42}$. The analytical error of biogenic opal content is less than $\pm 1 \%$.

Total inorganic carbon (TIC) content was measured using an $\mathrm{UIC} \mathrm{CO}_{2}$ Coulometer $\mathrm{CM} 5014$. The analytical error of TIC was $\pm 0.1 \%$ as a relative standard deviation. $\mathrm{CaCO}_{3}$ content was calculated by multiplying TIC contents by 8.333 ( $\mathrm{C}$ to $\mathrm{CaCO}_{3}$ ratio). Total carbon (TC) and total nitrogen (TN) contents were measured using an elemental analyzer (Flash 2000). The analytical errors were less than $\pm 0.1 \%$ and $\pm 0.01 \%$, respectively. TOC content was calculated as the difference between TC and TIC and C/N ratio was calculated by TOC/TN.

Carbon isotope of sediment organic matter $\left({ }^{13} \mathrm{C}_{\text {org }}\right)$ was measured from 82 horizons using Europa Scientific $20-20$ Elemental Analyser-Isotopes Ratio Mass Spectrometer (IRMS) at Iso-Analytical Ltd (UK). The expressed conventional delta notation is per mil deviation from the Vienna Pee Dee Belemnite (V-PDB) for the carbon isotope. Precision for carbon isotope was $\pm 0.1 \%$.

\section{Clay mineral analysis}

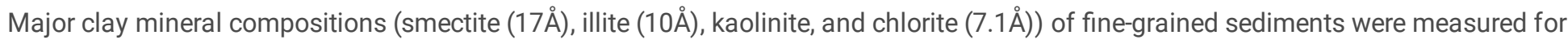
90 samples. Organic matter of bulk sediments was removed using $6 \%$ hydrogen peroxide solution. After wet-sieving through a $63 \mu \mathrm{m}$ mesh, clay particles $(<2 \mu \mathrm{m})$ were extracted using a settling technique based on Stoke's Law. The extracted clays were applied on glass slide into orientation ${ }^{42}$. The air-dried slides were scanned using X-ray diffractometer (XRD; SIEMENS/BRUKER D5005) at Gyeongsang National University (Korea) and repeated after ethylene glycol-saturating at $60^{\circ} \mathrm{C}$ during 24 hours ${ }^{44}$. The relative contents of the four major clay minerals were calculated semi-quantitatively according to the scheme reported by Biscaye $(1965)^{45}$. The proportion of kaolinite and chlorite was determined from their peak areas (3.58 and $3.54 \AA$ ), respectively ${ }^{46}$.

\section{Quantitative analysis for carbonates}

The contents of carbonate minerals (calcite and dolomite) were quantified for the 14 selected samples based on the prominent peaks of coarse fraction and TIC content. The bulk sediment powders were analyzed using the same XRD. According to the assumption that the carbonate minerals of the Arctic Ocean sediments consist mostly of calcite and dolomite ${ }^{34}$, TIC content was divided simply into calcite and dolomite proportions as below.

$$
\begin{aligned}
& \text { calcite }(\%)=\frac{\mathrm{RI}_{\text {calcite }}}{\left(\mathrm{RI}_{\text {calcite }}+\mathrm{RI}_{\text {dolomite }}\right)} \times \mathrm{TIC} \times 8.333 \\
& \text { dolomite }(\%)=\frac{\mathrm{RI}_{\text {calcite }}}{\left(\mathrm{RI}_{\text {calcite }}+\mathrm{RI}_{\text {dolomite }}\right)} \times \mathrm{TIC} \times 7.67
\end{aligned}
$$

where RI represents relative intensity of calcite $(3.04 \AA)$ and dolomite $(2.89 \AA ̊)$.

\section{Declarations}

\section{Acknowledgements}

This work is a contribution to the 5th Chinese National Arctic Research Expeditions (CHINARE-2012) conducted by R/V Xuelong. This study was supported by National Research Foundation of Korea (Grant No. 2016R1D1A1B03934308, 2019R1A2C1007701) and Chinese National Science Foundation (Grant No. 42176223).

\section{Author Contributions}


B.K.K. designed the research plan and was responsible for the experimental plan and data acquisition. K.P. is responsible for obtaining the laboratory experiments, interpreting analytical data, and writing the draft with the assistance of all authors. R.W. and W.X. provided the sediment samples and previous data in addition to the discussion with L.P. and H.G.C.

Competing interest: The authors declare that they have no competing interests.

\section{References}

1. Lisiecki, L. E., \& Raymo, M. E. A Pliocene-Pleistocene stack of 57 globally distributed benthic $\delta^{18} \mathrm{O}$ records. Paleoceanography 20 , PA1003, doi:10.1029/2004PA001071 (2005).

2. Imbrie, J., et al. On the structure and origin of major glaciation cycles 2 . The 100,000-year cycle. Paleoceanography 8, 699-735 (1993).

3. Jansen, J. H. F., Kuijpers, A., \& Troelstra, S. R. A mid-Brunhes climatic event: long-term changes in global atmosphere and ocean circulation. Science 232, 619-622 (1986).

4. Jouzel, J. et al. Orbital and millennial Antarctic climate variability over the past 800,000 years. Science 317, 793-796 (2007).

5. Lüthi, D. et al. High-resolution carbon dioxide concentration record $650,000-800,000$ years before present. Nature 453, 379-382 (2008).

6. Lang, N., \& Wolff, E. W. Interglacial and glacial variability from the last $800 \mathrm{ka}$ in marine, ice and terrestrial archives. Clim. Past 7, 361-380 (2011).

7. Miller, G. H. et al. Arctic amplification: can the past constrain the future? Quat. Sci. Rev. 29, 1779-1790 (2010).

8. Cronin, T. M. et al. Enhanced Arctic amplification began at the Mid-Brunhes Event 400,000 years ago. Sci. Rep. 7, 1-7 (2017).

9. Xiao, W. et al. Middle to Late Pleistocene Arctic paleoceanographic changes based on sedimentary records from Mendeleev Ridge and Makarov Basin. Quat. Sci. Rev. 228, 106105 (2020).

10. Polyak, L. et al. Late Quaternary stratigraphy and sedimentation patterns in the western Arctic Ocean. Glob. Planet. Change 68, 517 (2009).

11. Schubert, C. J., \& Stein, R. Deposition of organic carbon in Arctic Ocean sediments: terrigenous supply vs marine productivity. Org. Geochem. 24, 421-436 (1996).

12. Polyak, L., Best, K. M., Crawford, K. A., Council, E. A., \& St-Onge, G. Quaternary history of sea ice in the western Arctic Ocean based on foraminifera. Quat. Sci. Rev. 79, 145-156 (2013).

13. Park, K., Ohkushi, K. I., Cho, H. G., \& Khim, B. K. Lithostratigraphy and paleoceanography in the Chukchi Rise of the western Arctic Ocean since the last glacial period. Polar Sci. 11, 42-53 (2017).

14. Stein, R. Arctic Ocean sediments: processes, proxies, and paleoenvironment. Developments in Marine Geology (Vol. 2), (Elsevier, 2008).

15. Yamamoto, M., \& Polyak, L. Changes in terrestrial organic matter input to the Mendeleev Ridge, western Arctic Ocean, during the Late Quaternary. Glob. Planet. Change 68, 30-37 (2009).

16. Rella, S. F., \& Uchida, M. Sedimentary organic matter and carbonate variations in the Chukchi Borderland in association with ice sheet and ocean-atmosphere dynamics over the last $155 \mathrm{kyr}$. Biogeosciences 8, 3545-3553 (2011).

17. Stein, R., Grobe, H., \& Wahsner, M. Organic carbon, carbonate, and clay mineral distributions in eastern central Arctic Ocean surface sediments. Mar. Geol. 119, 269-285 (1994).

18. Bischof, J., Clark, D. L., \& Vincent, J. S. Origin of ice-rafted debris: Pleistocene paleoceanography in the western Arctic Ocean. Paleoceanography 11, 743-756 (1996).

19. Dong, L. et al. Sedimentary record from the Canada Basin, Arctic Ocean: implications for late to middle Pleistocene glacial history. Clim. Past 13, 511-531 (2017).

20. Bischof, J. F., \& Darby, D. A. Mid-to Late Pleistocene ice drift in the western Arctic Ocean: evidence for a different circulation in the past. Science 277, 74-78 (1997).

21. Xiao, W. et al. A sedimentary record from the Makarov Basin, Arctic Ocean, reveals changing middle to Late Pleistocene glaciation patterns. Quat. Sci. Rev. 270, 107176 (2021). 
22. Wahsner, M. et al. Clay-mineral distribution in surface sediments of the Eurasian Arctic Ocean and continental margin as indicator for source areas and transport pathways-a synthesis. Boreas 28, 215-233 (1999).

23. Spielhagen, R. F. et al. Arctic Ocean evidence for late Quaternary initiation of northern Eurasian ice sheets. Geology 25, 783-786 (1997).

24. Ortiz, J. D. et al. Provenance of Holocene sediment on the Chukchi-Alaskan margin based on combined diffuse spectral reflectance and quantitative X-Ray Diffraction analysis. Glob. Planet. Change 68, 73-84 (2009).

25. Darby, D. A. Kaolinite and other clay minerals in Arctic Ocean sediments. J. Sediment. Res. 45, 272-279 (1975).

26. Bradley, R. S., \& England, J. H. The Younger Dryas and the sea of ancient ice. Quat. Res. 70, 1-10 (2008).

27. Darby, D. A., Polyak, L., \& Bauch, H. A. Past glacial and interglacial conditions in the Arctic Ocean and marginal seas-a review. Prog. Oceanogr. 71, 129-144 (2006).

28. Polyak, L., \& Jakobsson, M. Quaternary sedimentation in the Arctic Ocean: Recent advances and further challenges. Oceanography 24, 52-64 (2011).

29. Ehlers, J., \& Gibbard, P. L. The extent and chronology of Cenozoic global glaciation. Quat. Int. 164, 6-20 (2007).

30. Bintanja, R., \& Van de Wal, R. S. W. North American ice-sheet dynamics and the onset of 100,000-year glacial cycles. Nature 454, 869-872 (2008).

31. Balco, G., \& Rovey, C. W. Absolute chronology for major Pleistocene advances of the Laurentide Ice Sheet. Geology 38, 795-798 (2010).

32. Batchelor, C. L. et al. The configuration of Northern Hemisphere ice sheets through the Quaternary. Nat. Commun. 10, 1-10 (2019).

33. Hodell, D. A., Channell, J. E., Curtis, J. H., Romero, O. E., \& Röhl, U. Onset of "Hudson Strait" Heinrich events in the eastern North Atlantic at the end of the middle Pleistocene transition ( 640 ka)? Paleoceanography 23, PA4218, doi:10.1029/2008PA001591 (2008).

34. Stein, R., Matthiessen, J., \& Niessen, F. Re-coring at Ice Island T3 site of key core FL-224 (Nautilus Basin, Amerasian Arctic): sediment characteristics and stratigraphic framework. Polarforschung 79, 81-96 (2010).

35. Masson-Delmotte, V. et al. EPICA Dome C record of glacial and interglacial intensities. Quat. Sci. Rev. 29, 113-128 (2010).

36. Clark, P. U. et al. The middle Pleistocene transition: characteristics, mechanisms, and implications for long-term changes in atmospheric $p \mathrm{CO}_{2}$. Quat. Sci. Rev. 25, 3150-3184 (2006).

37. Willeit, M., Ganopolski, A., Calov, R., \& Brovkin, V. Mid-Pleistocene transition in glacial cycles explained by declining $\mathrm{CO} 2$ and regolith removal. Sci. Adv. 5, eaav7337.Bassinot, F. C., Labeyrie, L. D., Vincent, E., Quidelleur, X., Shackleton, N. J., \& Lancelot, Y., 1994. The astronomical theory of climate and the age of the Brunhes-Matuyama magnetic reversal. Earth Planet. Sci. Lett. 126, 91108 (2019).

38. Cronin, T. M., Smith, S. A., Eynaud, F., O'Regan, M., \& King, J. Quaternary paleoceanography of the central arctic based on Integrated Ocean Drilling Program Arctic Coring Expedition 302 foraminiferal assemblages. Paleoceanography 23, PA1S18, doi:10.1029/2007PA001484 (2008).

39. Marzen, R.E., DeNinno, L.H., Cronin, T.M. Calcareous microfossil-based orbital cyclostratigraphy in the Arctic Ocean. Quat. Sci. Rev. 149, 109-121 (2016).

40. Cronin, T. M. et al. Interglacial paleoclimate in the Arctic. Paleoceanogr. Paleoclimatol. 34, 1959-1979 (2019).

41. DeMaster, D. J. The supply and accumulation of silica in the marine environment. Geochim. Cosmochim. Acta 45, 1715-1732 (1981).

42. Mortlock, R.A., \& Froelich, P.N. A simple method for the rapid determination of biogenic opal in pelagic marine sediments. Deep-Sea Res. 36, 1415-1426 (1989).

43. Stokke, P.R., \& Carson, B. Variation in clay mineral X-ray diffraction results with the quantity of sample mounted. J. Sediment. Res. 43, 957-964 (1973).

44. Brunton, G. Vapor pressure glycolation of oriented clay minerals. Am. Mineral. 40, 124-126 (1955).

45. Biscaye, P.E. Mineralogy and sedimentation of recent deep-sea clay in the Atlantic Ocean and adjacent seas and oceans. Geol. Soc. Am. Bull. 76, 803-832 (1965).

46. Biscaye, P.E. Distribution between kaolinite and chlorite in recent sediments by x-ray diffraction. Am. Mineral. 49, 1281-1289 (1964). 


\section{Figures}

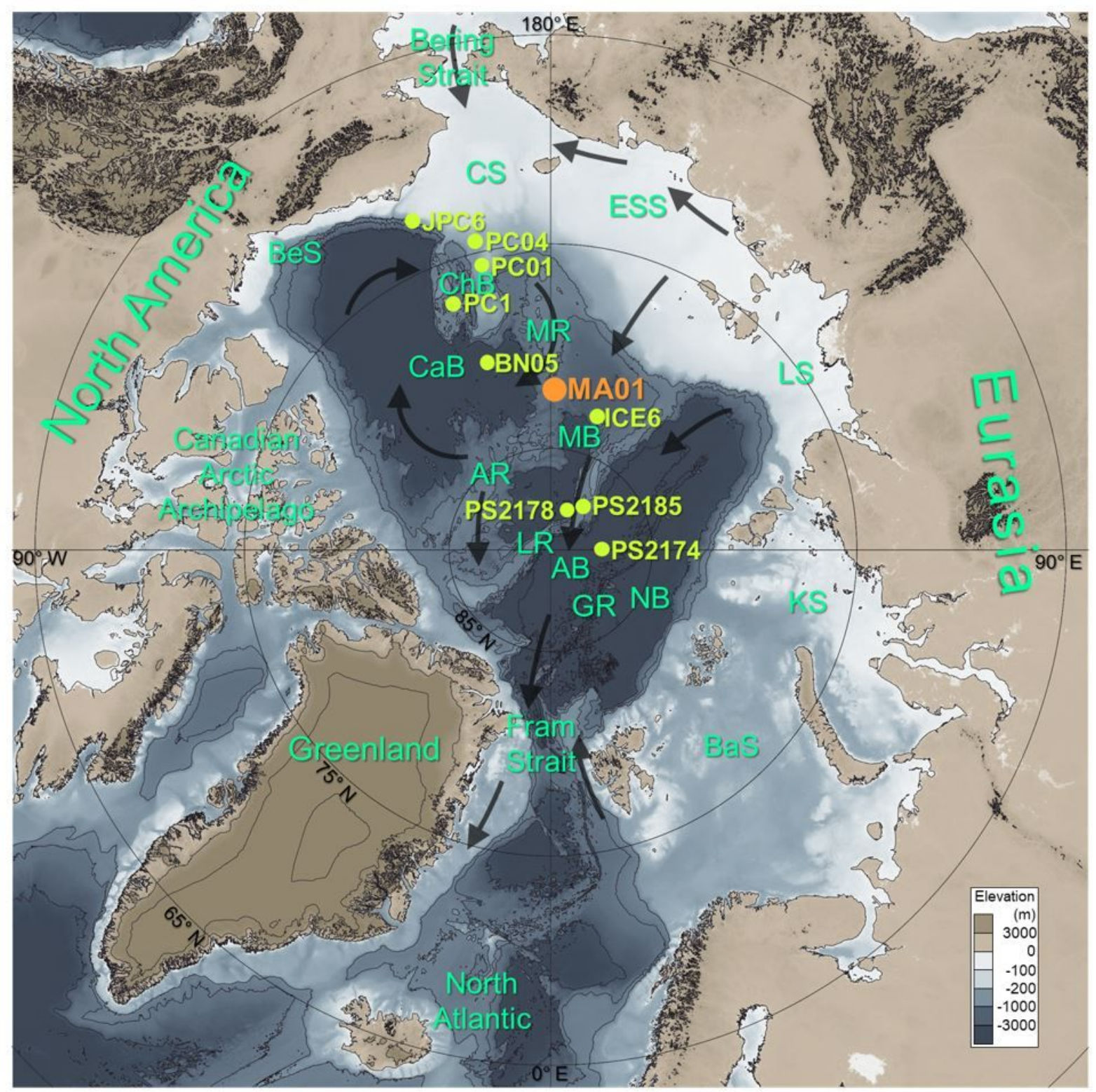

\section{Figure 1}

Geographic map showing the locations of cores in this study (ARC5-MA01) and referenced sites in the text (Table 1). The black arrows represent large-scale surface circulation system; clockwise Beaufort Gyre in the western Arctic Ocean and Transpolar Drift flowing from the Siberian shelves into the Fram Strait. BeS=Beaufort Sea; CS=Chukchi Sea; ESS=East Siberian Sea; LS=Laptev Sea; KS=Kara Sea; $\mathrm{BaS}=$ Barents Sea; $\mathrm{ChB}=$ Chukchi Borderland; $\mathrm{CaB}=$ Canada Basin; $\mathrm{MB}=$ Makarov Basin; $\mathrm{AB}=$ Amudsen Basin; NB=Nansen Basin;

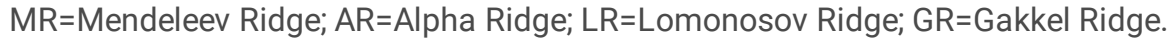




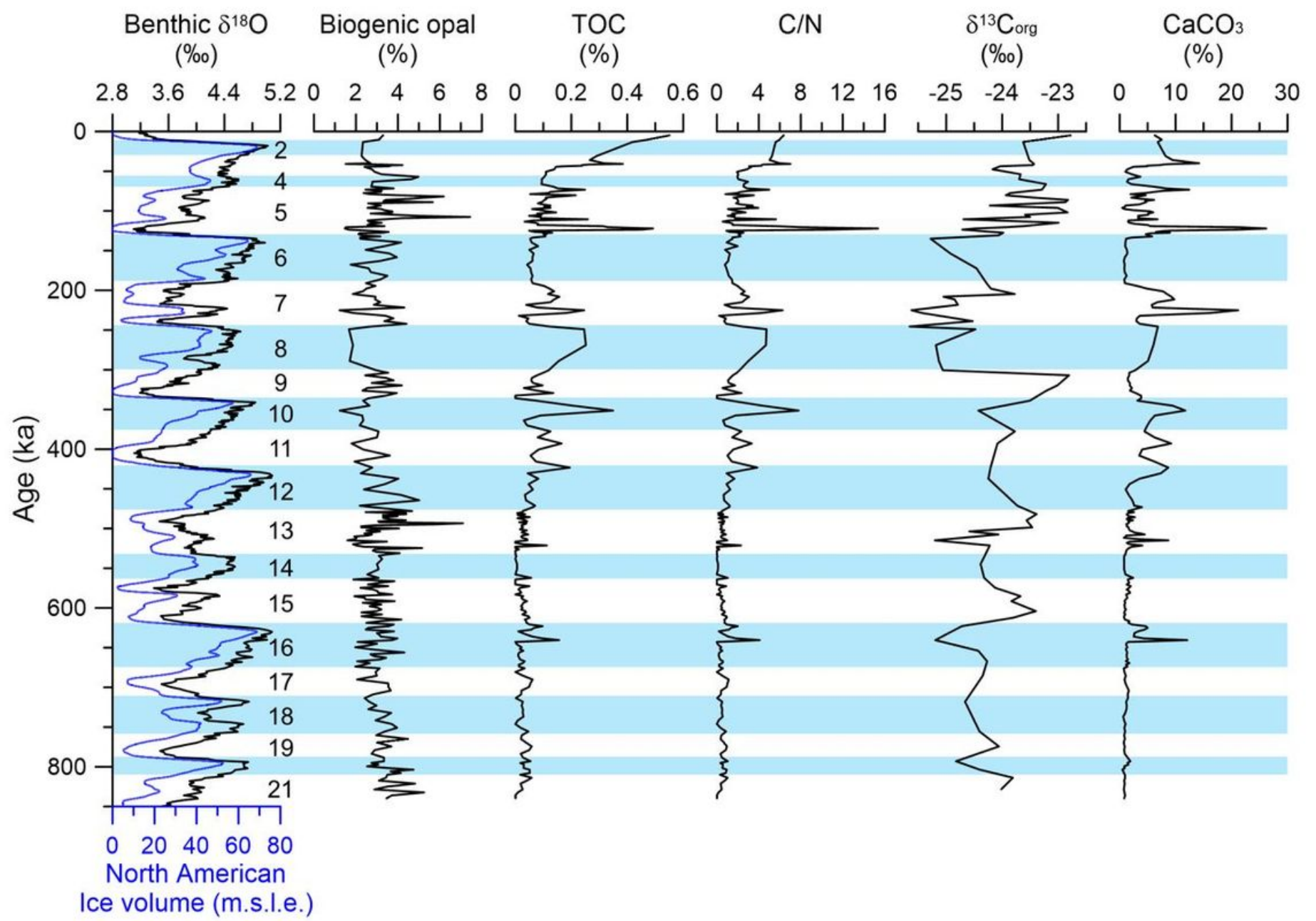

Figure 2

Downcore variation of the geochemical results (biogenic opal, TOC, $\mathrm{C} / \mathrm{N}, \delta^{13} \mathrm{C}_{\text {org }}$, and $\mathrm{CaCO}_{3}$ ) of core ARC5-MA01 along with global benthic $\delta^{18} \mathrm{O}$ values ${ }^{1}$ and North American ice volume (m.s.l.e.) ${ }^{30}$. Marine isotope stages (MIS) are indicated with blue shadings of glacial periods.
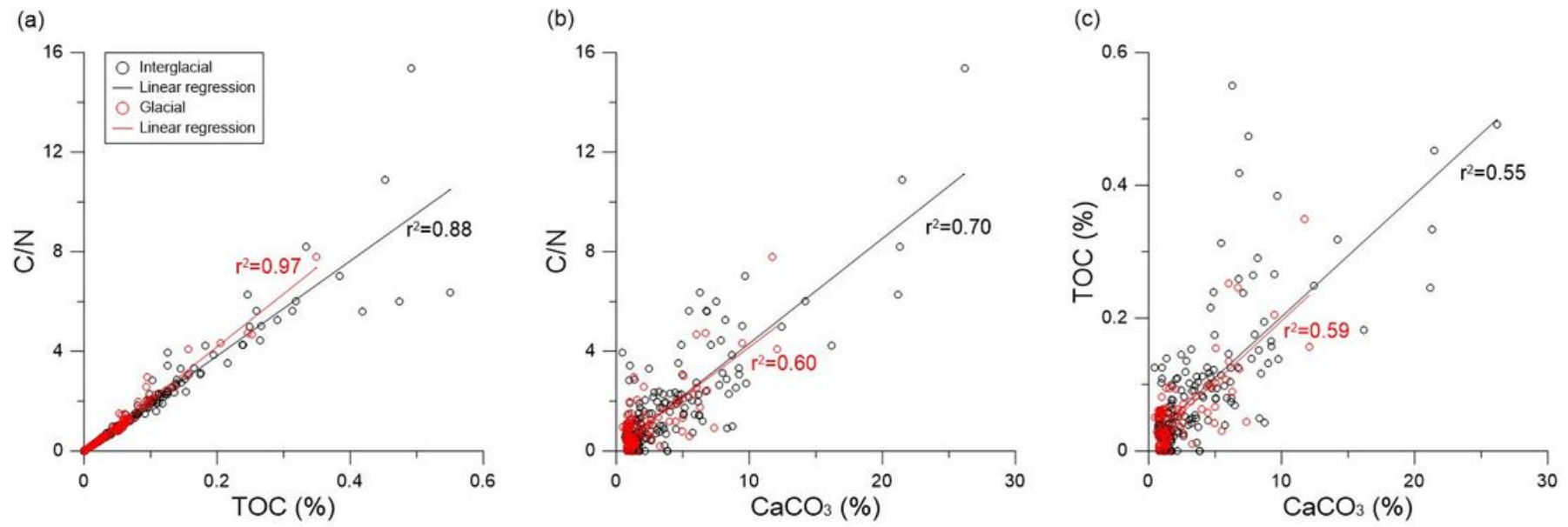

Figure 3 
Cross-plots between the geochemical results of core ARC5-MA01. (a) $\mathrm{C} / \mathrm{N}$ vs. TOC, (b) $\mathrm{C} / \mathrm{N}$ vs. $\mathrm{CaCO}_{3}$, and (c) TOC vs. $\mathrm{CaCO}_{3}$ with their correlation coefficient $\left(\mathrm{r}^{2}\right)$ during the glacial (red) and interglacial (black) periods, respectively.

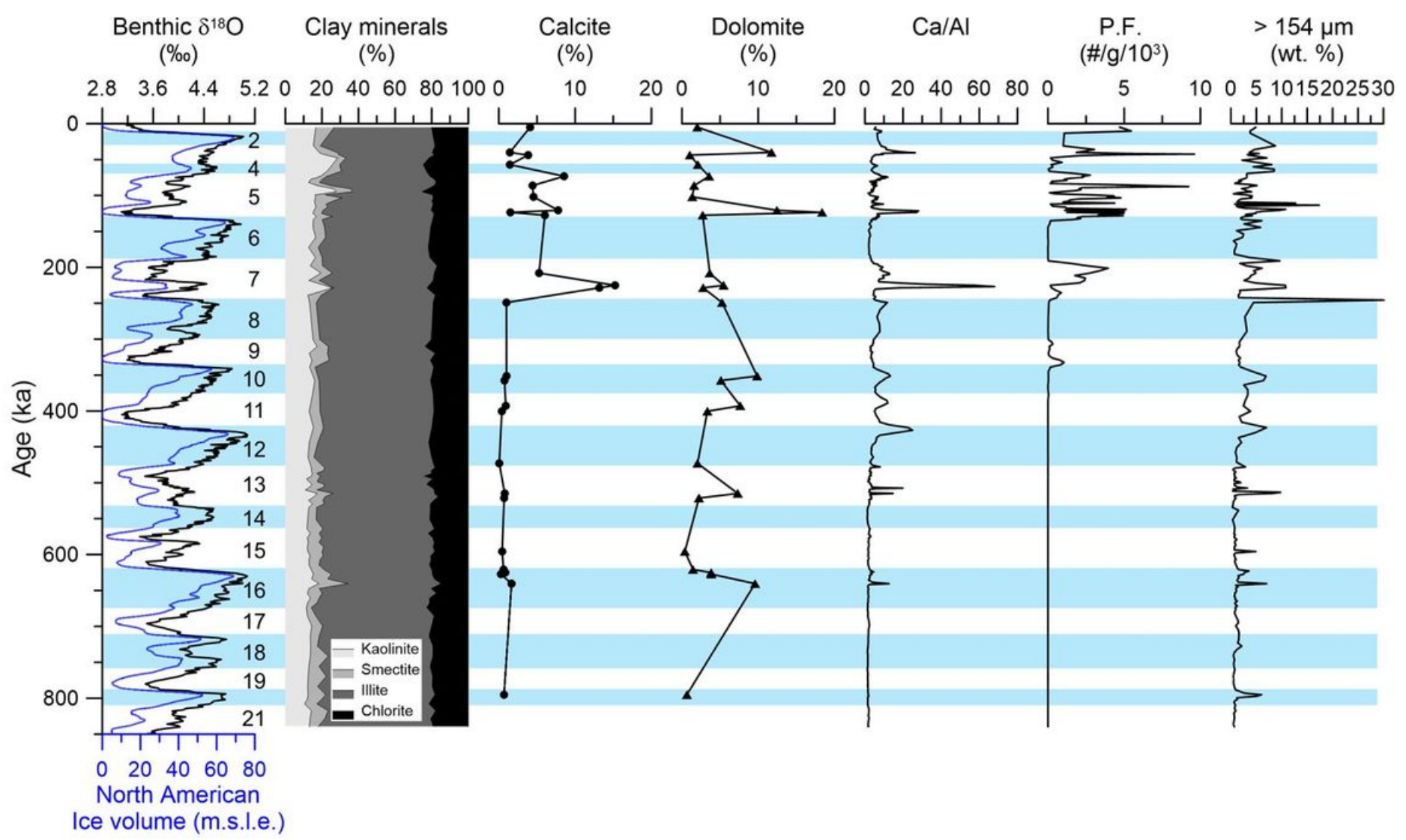

\section{Figure 4}

Downcore variation of mineralogical (four major clay minerals; kaolinite, smectite, illite, chlorite, and calcite and dolomite contents) results, XRF Ca/Al ratio, planktonic foraminiferal (P.F.) abundance ${ }^{9}$, and coarse-grained (>154 $\left.\mu \mathrm{m}\right)$ fraction ${ }^{9}$ of core ARC5-MA01 along with global benthic $\delta^{18} \mathrm{O}$ values ${ }^{1}$ and North American ice volume (m.s.l.e.) ${ }^{30}$. Marine isotope stages (MIS) are indicated with the blue shadings of glacial periods. Please refer to the supplementary Fig. S1 for detailed downcore variations of the major clay mineral contents.

(a) For the last $\sim 840$ kyrs

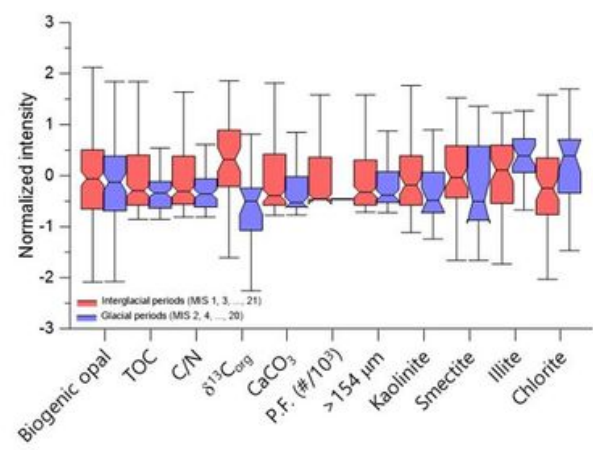

(b) Post-MBE

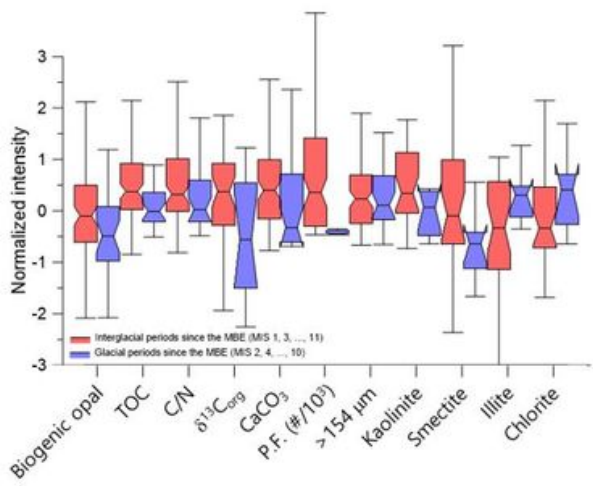

(c) Pre-MBE

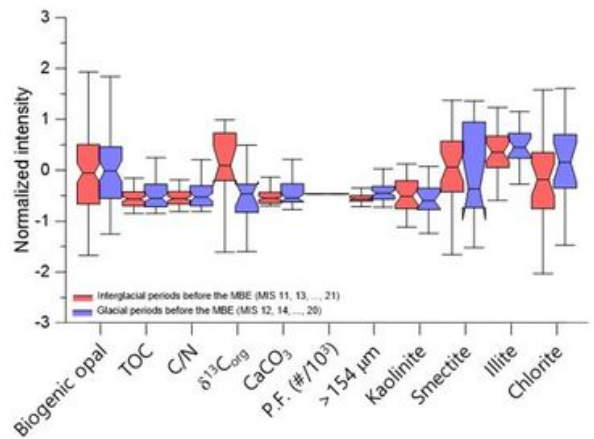

Figure 5 
Box-Whisker plots showing the normalized intensity values of the geochemical (biogenic opal, $\mathrm{TOC}, \mathrm{C} / \mathrm{N}, \delta^{13} \mathrm{C}_{\text {org }}$, and $\mathrm{CaCO}_{3}$ ), planktonic foraminifera (P.F.), and mineralogical (kaolinite, smectite, illite, and chlorite) data of core ARC5-MA01 for (a) the last 840 kyrs, (b) the post-MBE, and (c) the pre-MBE, respectively. The interquartile ranges multiplied by a factor of 1.5 are indicated as error bars. Red and blue boxes represent the interglacial and glacial periods, respectively.

\section{Supplementary Files}

This is a list of supplementary files associated with this preprint. Click to download.

- MA01dataset202101SR.xlsx

- SupplementaryFigureS1.docx 